\title{
PEMETAAN PEMBOROSAN DALAM PROSES PRODUKSI KANTONG SEMEN MENGGUNAKAN VALUE STREAM MAPPING TOOLS
}

\author{
Yesmizarti Muchtiar, Aidil Ikhsan, Ayu Bidiawati, JR \\ Program Studi Teknik Industri Universitas Bung Hatta \\ e-mail : yesmizartimuchtiar@bunghatta.ac.id
}

\begin{abstract}
ABSTRAK
Pemborosan pada proses produksi kantong semen merupakan aktivitas yang perlu direduksi. Value Stream Mapping Tools (VALSAT) dapat menggambarkan pemborosan di lantai produksi. Pada penelitian ini setelah aktivitas pembuatan kantong semen mulai dari supplier sampai ke tangan costumer yang diurai secara rinci menggunakan Diagram SIPOC maka terpilihlah tiga alat dari tujuh alat Valsat yang mempunyai korelasi paling tinggi. Alat yang terpilih adalah Process Activity Mapping, Qualitty Filter Mapping dan Demand Amplification Mapping. Dari kegiatan yang dipetakan melalui branstorming terlihat terjadi kelebihan produksi, cacat produk, pemborosan waktu dan terjadi gerakan yang tidak berguna. Dengan pemetaan ini diharapkan solusi untuk perbaikan sehingga pemborosan bisa diminimasi menjadi lebih terarah.
\end{abstract}

Kata kunci: Valsat, Pemborosan, Branstorming, Minimasi.

\begin{abstract}
Waste in production process of cement bag is an activity that needs to be reduced. Value Stream Mapping Tools (VALSAT) can describe the waste on the production floor. In this study, after the activity of making cement bag from the supplier to the customer hands parsed in detail using the SIPOC Diagram selected three of seven tools VALSAT tools that have the highest correlation. Selected tool is the Process Activity Mapping, and qualitty Filter Demand Amplification Mapping. From the activities that are mapped through branstorming seen happen over-production, defective product, a waste of time and useless movements occur. With this mapping solution is expected to be improved so that waste is minimized become more focused.
\end{abstract}

Keywords: VALSAT, Waste, Branstorming, Minimization

\section{PENDAHULUAN}

Dalam usaha peningkatan kualitas diperlukan pengendalian kualitas untuk mewujudkan produk yang berkualitas dengan harga yang lebih murah dan yang paling penting adalah kecepatan dalam menghasilkan produk sehingga sampai ke tangan konsumen tepat waktu. Perbaikan kualitas dan percepatan proses terhadap sistem produksi secara menyeluruh harus dilakukan jika perusahaan ingin mewujudkan target terciptanya produk berkualitas yang baik dalam waktu yang relatif singkat. Namun terdapat sebagian cacat dan pemborosan yang tidak bisa hilang, serta kecepatan produksi yang susah ditingkatkan. Sehingga untuk mencapai tujuan yang diinginkan maka perusahaan harus lebih efisien dalam keseluruhan proses produksi [1].

Meminimalkan pemborosan dalam proses produksi dapat menstimulasikan keunggulan bersaing perusahaan terutama pada PT. Semen Padang yang memproduksi sendiri kantong semen. Pabrik ini menghasilkan dua jenis kantong semen yaitu Pasted bag dan Sewing. Penelitian dilakukan hanya untuk produksi pasted bag. Peningkatan produktivitas akan tercapai bila adanya perampingan operasi yang dapat mengidentifikasi lebih dini pemborosan pada saat produksi. Adanya pemborosan (waste) di lantai produksi yaitu 1). Kelebihan produksi (overproduction), 2) Gerakan yang tidak berguna (unnecessary motion), 3). Transportasi yang berlebihan (excessive transportation), 4). Cacat (defect), 5). Proses yang tidak tepat (inapproriate processing), 6). Persediaan yang tidak penting (unnecessary inventory), dan 7). Waktu tunggu (waiting) adalah hal yang tidak diinginkan oleh perusahaan [1][2]. Maka pemborosan haruslah diminimasi atau bahkan dihilangkan dalam proses produksi [3].

Adapun tujuan dari penelitian ini adalah: 1). Menggambarkan proses produksi secara detil sehingga akan teridentifikasi pemborosan yang terjadi di lantai produksi. 2). Memilih Alat 
Pemetaan Aliran Nilai (Value Stream Mapping Tools- VALSAT) yang bisa memetakan pemborosan yang ditemukan. 3). Mencari akar permasalahan dan dampak yang terjadi karena adanya pemborosan sehingga bisa dicarikan solusi dengan tools yang tepat.

\section{Konsep Pemetaan Aliran Nilai Pemborosan}

\section{TINJAUAN PUSTAKA}

Pemborosan (waste) adalah segala aktivitas dalam proses kerja yang tidak memberikan nilai tambah bagi output (barang dan jasa) sepanjang value stream dan selanjutnya meningkatkan customer value [1]. Pemborosan akan memberikan dampak yang sangat serius bagi daya saing dan kelangsungan hidup perusahaan.

\section{Value Stream Mapping Tools [4]}

Value stream mapping adalah salah satu metode untuk memetakan aliran produksi dan aliran informasi untuk memproduksikan satu produk atau satu famili produk, tidak hanya pada masing masing area kerja, tetapi pada tingkat total produksi serta mengidentifikasi kegiatan yang value added dan non value added.

Waste didefinisikan sebagai beberapa aktifitas yang tidak memberikan nilai tambah kepada produk akhir. Value stream mapping juga dapat menyediakan titik awal untuk membantu manajemen, engineer, perkumpulan produksi, penjadwalan, supplier dan konsumen untuk menyadari waste dan mengidentifikasi penyebabnya.

Tabel 1. Keterkaitan Ketujuh Alat Pemetaan Aliran Nilai Dengan Ketujuh Jenis Waste [4]

\begin{tabular}{|c|c|c|c|c|c|c|c|}
\hline Waste & $\begin{array}{l}\text { Process } \\
\text { aktivity } \\
\text { mapping }\end{array}$ & $\begin{array}{l}\text { Supply chain } \\
\text { response } \\
\text { matrix }\end{array}$ & $\begin{array}{l}\text { Production } \\
\text { variety } \\
\text { funnel }\end{array}$ & $\begin{array}{l}\text { Quality } \\
\text { filter } \\
\text { mapping }\end{array}$ & $\begin{array}{l}\text { Demand } \\
\text { amplification } \\
\text { mapping }\end{array}$ & $\begin{array}{l}\text { Decision } \\
\text { point } \\
\text { analysis }\end{array}$ & $\begin{array}{l}\text { Physical } \\
\text { structure }\end{array}$ \\
\hline $\begin{array}{l}\text { Kelebihan } \\
\text { Produksi }\end{array}$ & $\mathrm{L}$ & M & & $\mathrm{L}$ & M & M & \\
\hline Waktu tunggu & $\mathrm{H}$ & $\mathrm{H}$ & $\mathrm{L}$ & & $\mathrm{M}$ & $\mathrm{M}$ & \\
\hline $\begin{array}{l}\text { Transportasi } \\
\text { yang berlebihan }\end{array}$ & $\mathrm{H}$ & & & & & & $\mathrm{L}$ \\
\hline $\begin{array}{l}\text { Proses yang } \\
\text { tidak tepat }\end{array}$ & $\mathrm{H}$ & & M & $\mathrm{L}$ & & $\mathrm{L}$ & \\
\hline $\begin{array}{l}\text { Persediaan yang } \\
\text { tidak penting }\end{array}$ & M & $\mathrm{H}$ & M & & $\mathrm{H}$ & M & $\mathrm{L}$ \\
\hline $\begin{array}{l}\text { Gerakan yang } \\
\text { tidak berguna }\end{array}$ & $\mathrm{H}$ & $\mathrm{L}$ & & & & & \\
\hline Cacat & $\mathrm{L}$ & & & $\mathrm{H}$ & & & \\
\hline
\end{tabular}

Catatan :

$\mathrm{H}$ : Tingginya kolerasi dan kegunaan

$\mathrm{M}$ : Sedang kolerasi dan kegunaan

L : Rendahnya kolerasi

\section{Fungsi Value Stream Mapping}

Value Stream Mapping mempunyai beberapa fungsi yaitu:

1) Value Stream Mapping adalah alat peraga untuk menjelaskan Value Stream yang sekarang.

2) Supaya orang mengerti dengan mudah dimana waste berada dalam proses

3) Memberikan tim perbaikan sebuah landasan untuk memprioritaskan usaha perbaikan.

4) Memberikan tim sebuah alat peraga untuk mewakili ide perbaikan mereka, jadi tim dapat lebih baik untuk berkomunikasi dengan orang yang di dalam maupun di luar organisasi. 


\section{Process Activity Mapping}

Process activity mapping memberikan gambaran aliran fisik dan informasi, waktu yang diperlukan untuk setiap aktivitas, jarak yang ditempuh dan tingkat persediaan produk dalam setiap tahap produksi. Kemudahan identifikasi aktivitas terjadi karena adanya pergolongan aktivitas menjadi 5 jenis yaitu operasi, transportasi, inpeksi, delay, dan penyimpanan. Operasi dan inspeksi adalah aktivitas yang bernilai tambah. Sedangkan transportasi dan penyimpanan berjenis penting tetapi tidak bernilai tambah. Adapun delay adalah aktivitas yang dihindari untuk terjadi sehingga merupakan aktivitas berjenis tidak bernilai tambah

\section{Supply Chain Response Matrix}

Supply chain response matrix digunakan untuk mengevaluasi persediaan dan lead time sehingga meningkatkan tingkat pelayanan pada jalur distribusi yang dilakukan dengan biaya yang lebih rendah. Dengan tools ini pihak manajemen akan mengetahui peningkatan atau penurunan tingkat persediaan dan waktu distribusi pada tiap area dalam supply chain.

\section{Production Variety Funnel}

Production variety funnel merupakan alat yang berasal dari disiplin ilmu manajemen operasi dan telah pernah diaplikasikan oleh New [5] pada industri tekstil. Metode ini berguna untuk mengetahui pada area mana terjadi bottleneck dari input bahan baku, proses produksi sampai pengiriman ke konsumen. [4]

\section{Quality Filter Mapping}

Quality Filter Mapping adalah hasil identifikasi menunjukkan adanya 3 jenis defect dari kualitas yaitu (1) produk defect (2) scrap defect (3) service defect. Product defect merupakan cacat fisik produk yang tidak berhasil diseleksi pada saat proses inspeksi sehingga lolos ke konsumen. Untuk memaparkan permasalahan kualitas di atas terutama untuk cacat maka quality filter mapping menggunakan data cacat produksi yang digunakan umtuk mengetahui persen cacat tersebut. Dari persen cacat akan terlihat jelas apakah jumlah cacat melewati batasan yang ditetapkan perusahaan.

Persen cacat produksi $=\frac{\text { Jumlah cacat }}{\text { Total cacat }}$

\section{Demand Amplification Mapping}

Demand amplification mapping adalah alat yang sering digunakan pada disiplin ilmu sistem dinamik yang diciptakan oleh Forester [6] dan Burbidge [7]. Hasil penelitian Burbidge [7] menunjukkan bahwa jika permintaan dikirim dari serangkaian persediaan yang dimiliki menggunakan pengendalian stock order, akan memperlihatkan adanya amplifikasi dari variasi permintaan akan meningkat untuk setiap transfer [6]. Hal ini menunjukkan bahwa pengaturan persediaan sangat penting dalam mengantisipasi adanya perubahan permintaan. Alat ini dapat digunakan sebagai dasar pengambilan keputusan dan analisis kedepan untuk mendesain konfigurasi aliran nilai, mengatur fluktuasi permintaan sehingga permintaan yang ada dapat dikendalikan.

\section{Decision Point Analysis}

Alat decision point analysis ini sering digunakan pada pabrik yang berkarakteristik produk jadinya relatif beragam dari jumlah komponen yang terbatas, seperti industri elektronik dan rumah tangga. Akan tetapi pada perkembangannya juga digunakan pada industri lain. Titik keputusan adalah dimana tarikan permintaan aktual memberikan cara untuk mendorong adanya peramalan. Adanya informasi titik keputusan akan berguna untuk mengerti dimana terjadinya 
kekeliruan penentuan titik keputusan.

\section{Physical Structure}

Alat ini berguna untuk mengetahui fakta apa yang terjadi pada aliran rantai pasok secara keseluruhan dan mengetahui level dari industrinya. Adanya pengetahuan dari alat ini, akan sangat berguna mengapresiasikan seperti apa industri manufaktur sekarang, mengerti bagaiman perusahaan beroperasi dan dapat memperhatikan secara langsung area mana perlu perhatian khusus untuk dikembangkan.

\section{METODOLOGI PENELITIAN}

Secara teoritis pemborosan di lantai produksi ada 7, yaitu [1][2]:

a. kelebihan produksi (over production),

b. gerakan yang tidak berguna (unnecessary movement),

c. transportasi yang berlebih (excessive transportation),

d. cacat (defect),

e. proses yang tidak tepat (inapproriate processing),

f. persediaan yang tidak penting (unnecessary inventory) dan

g. waktu tunggu (waiting).

Tahap awal penelitian dilakukan dengan menggambarkan aliran proses di lantai produksi menggunakan Diagram SIPOC (Supplier-Input-Process-Output-Customer). Survey secara langsung ke tempat penelitian akan membantu mendapatkan gambaran secara aktual proses yang ada di lapangan.

Value Stream Mapping Tools dengan tujuh alatnya digunakan untuk memetakan pemborosan tersebut. Pemilihan dilakukan dengan melihat keterkaitan antara tujuh alat Value Stream Mapping dengan pemborosan yang ada [4].

Untuk mendapatkan metoda dalam mereduksi pemborosan dicari permasalahan dan dampak dari pemborosan yang ada di lantai produksi. Dalam penelitian ini dilakukan dengan branstorming pada karyawan Pabrik Kantong PT. Semen Padang

\section{HASIL DAN PEMBAHASAN}

Untuk mengetahui aliran produksi dilakukan dengan survey secara langsung ke perusahaan. Pengidentifikasian dimulai dari Suplier sampai produk ke tangan Costumer. Identifikasi dilakukan menggunakan Diagram SIPOC (Supplier-Input-Process-Output-Customer). Penggambaran dilakukan secara bertahap dan rinci.

1. Diagram SIPOC dari Suppliers

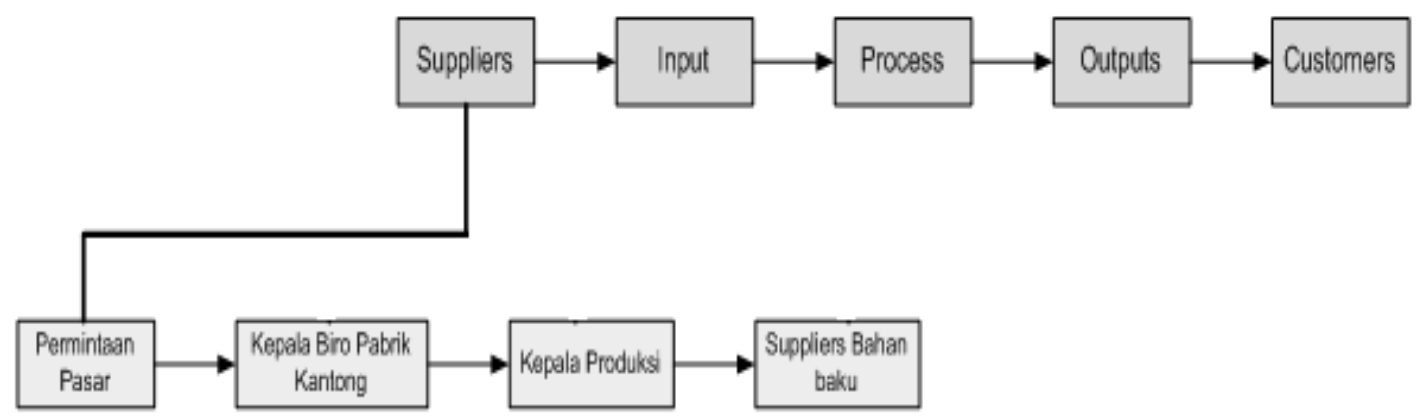

Gambar 1. Diagram SIPOC Dari Suppliers

Pada saat ini, sering kali terjadi misscomunication antara bagian permintaan pasar dan kepala produksi. Sehingga produksi sering berlebih dan mengakibatkan penumpukan kantong 
semen yang sudah jadi pada warehouse sehingga mengakibatkan penambahan biaya inventory dan kualitas kantong menjadi kurang baik.

2. Diagram SIPOC dari Input

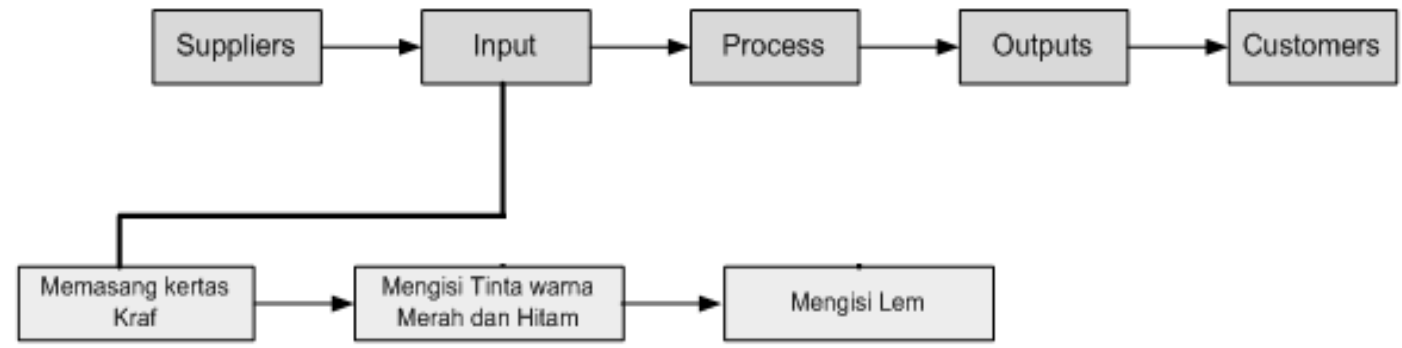

Gambar 2. Diagram SIPOC Dari Input Pembuatan Kantong

Pemasangan kertas kraf pada paper reel stand unit dilakukan dengan menggunakan alat bantu crane. Pada saat pengisian tinta print dilakukan secara manual oleh operator dengan menggunakan ember kemudian lem dituang ke bak penampungan lem menggunakan alat glue mixer.

3. Diagram SIPOC Dari Proses

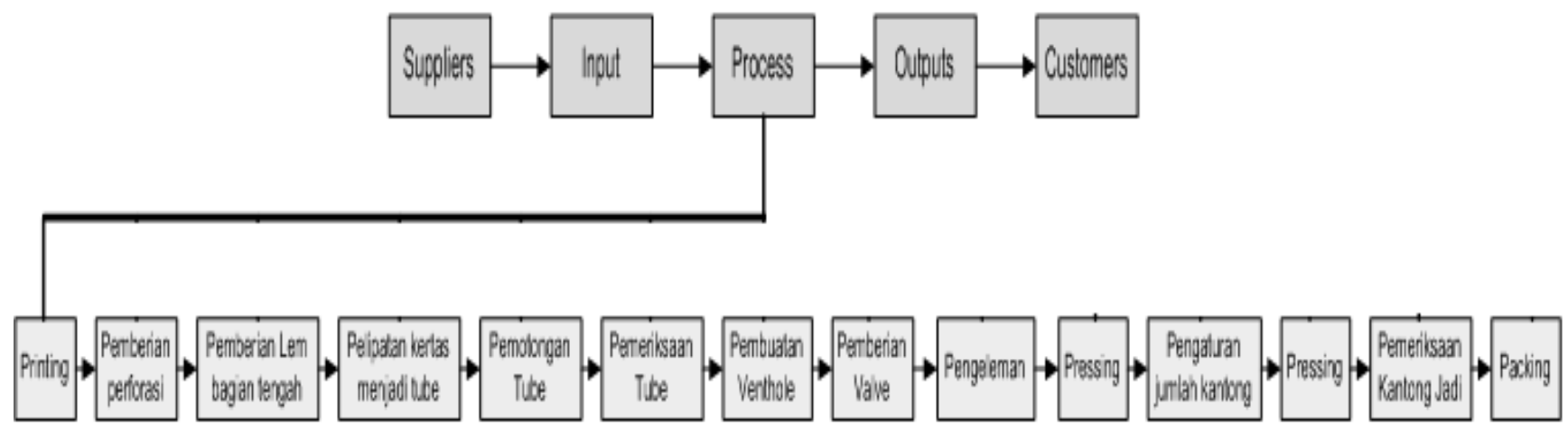

Gambar 3. Diagram SIPOC Dari Proses Pembuatan Kantong

Pada proses produksi kantong semen ini sering terjadi kendala seperti kertas kraf putus yang di disebabkan oleh bahan baku yang tidak baik. Pengeleman tidak rapi atau tidak penuh yang disebabkan oleh lem habis pada penampungan lem dan tidak diketahui oleh operator. Pemotongan tidak tepat pada yang di tentukan, karena pengaturan yang dilakukan oleh operator tidak tepat sehingga mengakibatkan delay pada proses produksi dan proses produksi kantong semen tidak memenuhi target permintaan.

4. Diagram SIPOC dari Input 


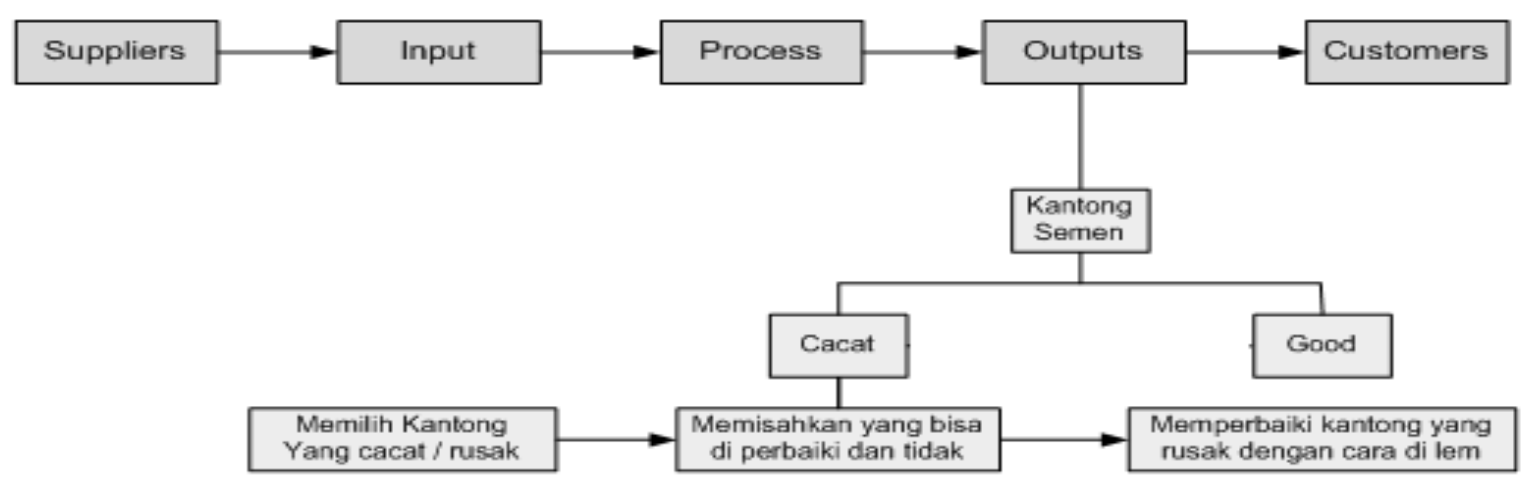

Gambar 4. Diagram SIPOC Dari Output Pembuatan Kantong

Output dari hasil proses produksi adalah kantong semen. Kantong semen yang dihasilkan tidak $100 \%$ bagus. Ada beberapa kantong semen yang ditemukan cacat pada saat inspeksi dilakukan sebelum diletakkan di palet. Kantong semen yang cacat dipisahkan dari kantong semen yang baik untuk dipisah, produk yang masih bisa diperbaiki atau tidak. Kantong semen yang bisa diperbaiki di kumpulkan menjadi satu untuk diberi lem kembali pada bagian yang kekurangan lem. Sedangkan kantong semen yang tidak bisa diperbaiki akan dimasukkan kedalam tempat penampungan.

Pada proses ini terlihat gerakan yang tidak berguna seperti pengumpulan kembali kantong semen yang cacat dari hasil inspeksi akhir kantong semen. Hal ini disebabkan karena tidak adanya tempat untuk menyimpan kantong semen yang cacat. Sehingga kantong semen yang cacat diletakkan di lantai dan berserakan di lokasi inspeksi. Dalam proses perbaikan juga terjadi hal seperti itu, karena tidak ada tempat untuk hasil perbaikan kantong semen yang cacat. Ini menyebabkan kantong yang sudah diperbaiki tercampur dengan kantong yang belum diperbaiki.
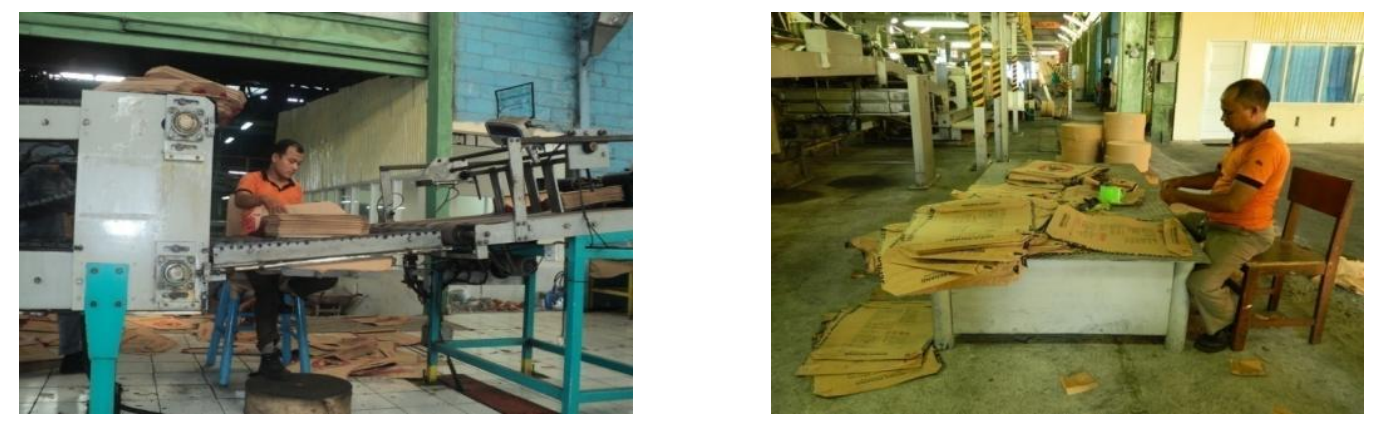

Gambar 5. Kantong Yang Berserakan Dan Perbaikan Kantong Semen Yang Cacat

5. Diagram SIPOC Customers

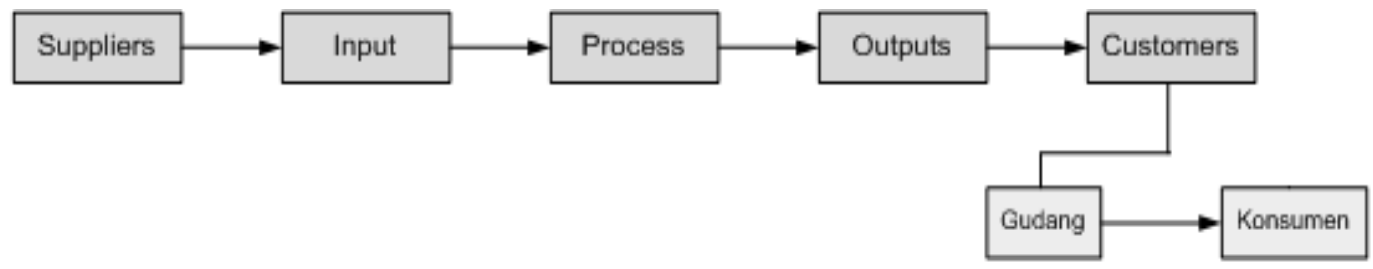

Gambar 6. Diagram SIPOC Customers ke Ware House Kantong

\section{Value Stream Mapping}

Pemborosan yang ditemui pada SIPOC adalah:

1) Kelebihan Produksi

2) Cacat Produk 
3) Waktu Tunggu

4) Gerakan yang tidak berguna

Dari empat pemborosan di atas maka digunakan tabel VALSAT [8] untuk menetapkan peta yang akan digunakan. Pemilihan peta dilihat dari tingkat kolerasi dan kefaedaan. Terpilih tiga peta yang bisa menggambarkan pemborosan yang ada dalam proses produksi yaitu Process Activity Mapping, Quality Filter Mapping dan Demand Amplification Mapping.

\section{Process Activity Mapping}

Tabel 2. Process Activity Mapping

\begin{tabular}{|c|c|c|c|c|c|c|c|c|c|c|c|}
\hline \multirow{2}{*}{ No } & \multirow{2}{*}{ Kegiatan } & \multirow{2}{*}{ Flow } & \multirow{2}{*}{ Mesin } & \multirow{2}{*}{$\begin{array}{c}\text { Jarak } \\
\text { m } \\
\end{array}$} & \multirow{2}{*}{$\begin{array}{c}\text { Waktu } \\
\text { dtk } \\
\end{array}$} & \multicolumn{5}{|c|}{ Aktivitas } & \multirow{2}{*}{ Keterangan } \\
\hline & & & & & & $\mathbf{O}$ & $\mathbf{T}$ & $\mathbf{I}$ & $\mathbf{S}$ & D & \\
\hline \multicolumn{12}{|c|}{ Proses mengganti tanggal pada printing unit } \\
\hline 1 & Pemasangan lem & $\mathrm{O}$ & & & 126 & $\mathrm{O}$ & $\mathrm{T}$ & I & $\mathrm{S}$ & $\mathrm{D}$ & \multirow{3}{*}{$\begin{array}{l}\text { Penempelan } \\
\text { memakai lem aibon }\end{array}$} \\
\hline 2 & Proses pengeringan lem & $\mathrm{D}$ & & & 405 & $\mathrm{O}$ & $\mathrm{T}$ & I & S & $\mathrm{D}$ & \\
\hline 3 & Pemasangan tanggal & $\mathrm{O}$ & & & 55 & $\mathrm{O}$ & $\mathrm{T}$ & I & $S$ & $\mathrm{D}$ & \\
\hline \multicolumn{12}{|c|}{ Proses Pengisian Tinta Pada Printing unit } \\
\hline 4 & $\begin{array}{l}\text { Pengambilan tinta merah } \\
\text { dan hitam }\end{array}$ & $\mathrm{T}$ & $\begin{array}{c}\text { Hand } \\
\text { lift }\end{array}$ & 10 & 150 & $\mathrm{O}$ & $\mathrm{T}$ & I & $S$ & $\mathrm{D}$ & \multirow{5}{*}{$\begin{array}{l}\text { Dilakukan secara } \\
\text { manual } \\
\text { Agar tinta tidak } \\
\text { menggumpal } \\
\text { Mengisi dari kaleng } \\
\text { tinta ke bak tinta } \\
\text { Agar tinta tidak } \\
\text { menggumpal } \\
\text { Mengisi dari kaleng } \\
\text { tinta ke bak tinta } \\
\end{array}$} \\
\hline 5 & Mengaduk tinta merah & $\mathrm{O}$ & & & 10 & $\mathrm{O}$ & $\mathrm{T}$ & I & $\mathrm{S}$ & $\mathrm{D}$ & \\
\hline 6 & $\begin{array}{l}\text { Pengisian tinta merah ke } \\
\text { bak tinta merah }\end{array}$ & $\mathrm{O}$ & $\begin{array}{l}\text { Gayung, } \\
\text { ember }\end{array}$ & & 20 & $\mathrm{O}$ & $\mathrm{T}$ & I & $\mathrm{S}$ & $\mathrm{D}$ & \\
\hline 7 & Mengaduk tinta hitam & $\mathrm{O}$ & $\begin{array}{l}\text { Tongkat } \\
\text { kayu }\end{array}$ & & 10 & $\mathrm{O}$ & $\mathrm{T}$ & I & S & $\mathrm{D}$ & \\
\hline 8 & $\begin{array}{l}\text { Pengisian tinta hitam ke } \\
\text { bak tinta hitam }\end{array}$ & $\mathrm{O}$ & $\begin{array}{l}\text { Gayung, } \\
\text { ember }\end{array}$ & & 20 & $\mathrm{O}$ & $\mathrm{T}$ & I & $S$ & $\mathrm{D}$ & \\
\hline \multicolumn{12}{|c|}{ Proses Pengisian Lem Pada Pasting Unit } \\
\hline 9 & $\begin{array}{l}\text { Membawa ember ke glue } \\
\text { mixer }\end{array}$ & $\mathrm{T}$ & $\begin{array}{c}\text { Hand } \\
\text { lift }\end{array}$ & 6 & 15 & $\mathrm{O}$ & $\mathrm{T}$ & I & $S$ & $\mathrm{D}$ & $\begin{array}{l}\text { Dilakukan secara } \\
\text { manual }\end{array}$ \\
\hline \multicolumn{12}{|c|}{ 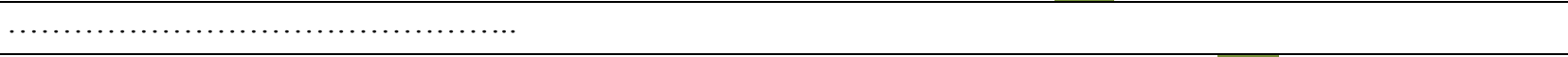 } \\
\hline 29 & Menunggu froklift & $\mathrm{D}$ & $\begin{array}{c}\text { Hand } \\
\text { lift }\end{array}$ & & 150 & $\mathrm{O}$ & $\mathrm{T}$ & I & $\mathrm{S}$ & $\mathrm{D}$ & \multirow{3}{*}{ Mengangkut 2 pallet } \\
\hline 30 & $\begin{array}{l}\text { Penyimpanan pasted bag } \\
\text { ke gudang }\end{array}$ & $S$ & froklift & 15 & 120 & $\mathrm{O}$ & $\mathrm{T}$ & I & $\mathrm{S}$ & $\mathrm{D}$ & \\
\hline & Total & & & & 45104 & & & & & & \\
\hline
\end{tabular}

Tabel 3. Kebutuhan Waktu Aktifitas Proses Produksi Pasted Bag

\begin{tabular}{cccccc}
\hline & Operasi & Transportasi & Inspeksi & Storage & Delay \\
\hline Total Waktu & 42614 & 335 & 20 & 120 & 1995 \\
Persentase & 94,48 & 0,75 & 0,04 & 0,27 & 4,42 \\
\hline
\end{tabular}

Dari hasil Process Activity Mapping, total waktu operasi mencapai kebutuhan waktu yang paling tinggi 42.433 detik. Dapat dilakukan eliminasi delay karena kegiatan tersebut tidak bernilai tambah. Dengan Process Activity Mapping dapat diketahui waktu yang dibutuhkan pada setiap proses produksi pasted bag, sehingga untuk proses selanjutnyat dapat mencegah terjadinya waste dan mempercepat proses produksi.

\section{Proses Pengeleman}

Dari Process Activity Mapping terdapat aktivitas yang memakan lama waktu operasi yaitu terdapat pada mesin Bottomer pada aktivitas pemasangan lem dengan waktu 126 detik dan menunggu lem kering 405 detik. Di pemetaan hasil Process Activity Mapping lama waktu aktivitas pemasangan lem diakibatkan karena pemasangan dilakukan secara manual. 


\section{Gerakan Tidak Berguna}

Dari Process Activity Mapping juga terdapat akifitas yang tidak berguna yaitu gerakan yang tidak berguna pada penyeleksian kantong semen yang cacat. Gerakan tidak berguna merupakan kegiatan yang tidak bernilai tambah. Hal ini disebabkan karena tidak adanya pemisahan tempat untuk kantong semen yang cacat.

\section{Qualitty Filter Mapping}

Mesin yang digunakan dalam pembuatan pasted bag terdiri dari mesin potong dan mesin Bottomer. Berdasarkan identifikasi kedua mesin tersebut sering mengalami kerusakan. Akibatnya timbul cacat produk yang dihasilkan pada mesin tersebut. Perusahaan menetapkan cacat pada mesin potong maksimal $0,1 \%$ dan cacat pada mesin bottomer $0,1 \%$

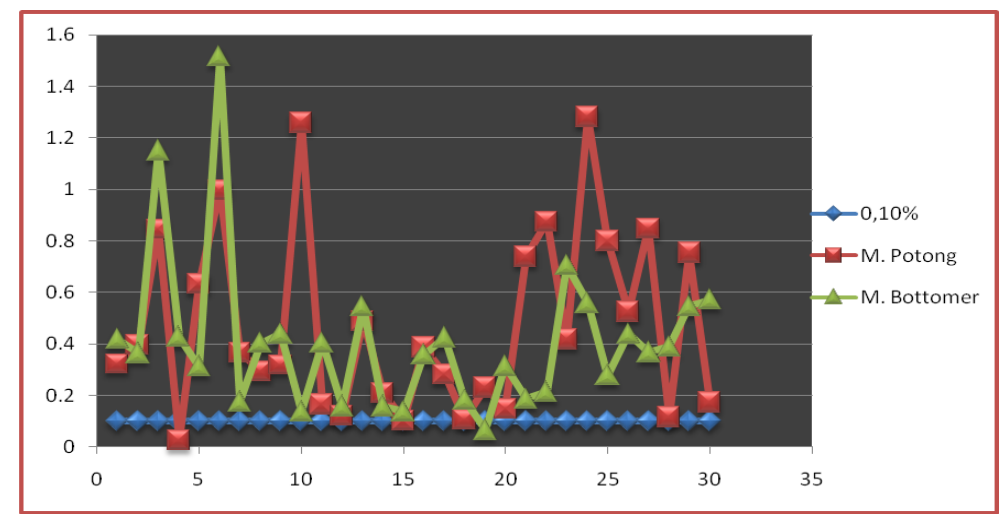

Gambar 7. Quality Filter Mapping

Dari data yang ada pada tanggal 1-30 April 2013, menunjukkan bahwa cacat mesin potong dan mesin bottomer melebihi ambang maksimal dari toleransi yang diberikan perusahaan. Dengan demikian perusahaan harus melakukan perbaikan untuk mengurangi terjadinya cacat dalam proses produksi pembuatan kantong semen jenis pasted bag.

\section{Demand Amplification Mapping}

Data yang dibutuhkan untuk pembuatan mapping ini adalah:

a. Data permintaan produk kantong semen

b. Data Production produk kantong semen

c. Data pengiriman produk kantong semen

Sisa hasil produksi $\quad=$ Tingkat produksi - tingkat permintaan

$$
=6.948 .074-6.193 .000=755.074 \text { helai }
$$

Berdasarkan dari data diatas didapat kelebihan produksi mencapai 755.074 helai kantong semen. Hal ini dapat mengakibatkan tingginya biaya inventori. Dari grafik dapat di ketahui permintaan kantong semen yang tidak stabil dan produksi memproduksi secara tetap. 


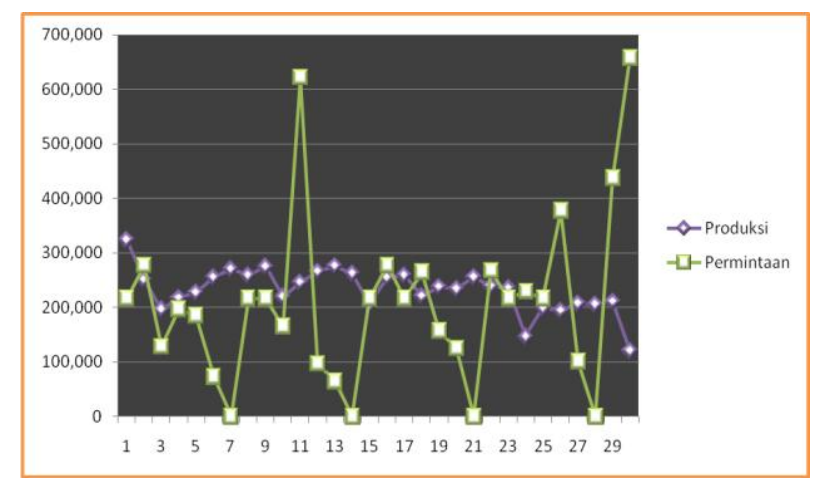

Gambar 11. Demand Amplification Mapping

\section{Penentuan Akar Masalah}

Aplikasi mengunakan tiga alat dari VALSAT akan menjadi acuan dalam proses perbaikan. Sebelum melakukan perbaikan dilakukan analisa dari penyebab pemborosan yang ada. Analisa dampak dilakukan dengan menggunakan branstorming. Dari dampat yang terlihat nantinya akan lebih mudah mencari solusi masalah yang ada [8].

Tabel 4. Rekapitulasi Permasalahan dan Dampak Pemborosan

\begin{tabular}{|c|c|c|}
\hline Pemborosan & Permasalahan & Dampak \\
\hline \multirow{2}{*}{ Kelebihan Produksi } & $\begin{array}{l}\text { Menurunnya permintaan } \\
\text { konsumen terhadap kantong } \\
\text { semen }\end{array}$ & $\begin{array}{l}\text { Produksi kantong semen menjadi } \\
\text { berlebih dan menambah biaya } \\
\text { penyimpanan }\end{array}$ \\
\hline & $\begin{array}{l}\text { Kurangnya komunikasi } \\
\text { antara bagian pemasaran } \\
\text { dan bagian produksi }\end{array}$ & $\begin{array}{l}\text { Departemen produksi memproduksi } \\
\text { seperti biasa sehingga mengakibatkan } \\
\text { kelebihan produksi }\end{array}$ \\
\hline \multirow{2}{*}{ Cacat Produk } & $\begin{array}{l}\text { Material dan supplier } \\
\text { Reject }\end{array}$ & $\begin{array}{l}\text { Menghambat proses produksi } \\
\text { Adanya pemborosan material }\end{array}$ \\
\hline & Penanganan kemasan reject & $\begin{array}{l}\text { Kehilangan kesempatan pengiriman } \\
\text { Produk reject menumpuk di area kerja }\end{array}$ \\
\hline \multirow{4}{*}{ Waktu Tunggu } & $\begin{array}{l}\text { Proses order produk melalui } \\
\text { pemasaran indarung }\end{array}$ & $\begin{array}{l}\text { Lead time pemesanan menjadi lebih } \\
\text { lama }\end{array}$ \\
\hline & $\begin{array}{l}\text { Downtime mesin bottomer } \\
\text { dan mesin potong }\end{array}$ & $\begin{array}{l}\text { Utilitas mesin rendah, lebih banyak } \\
\text { produk cacat }\end{array}$ \\
\hline & Proses set up mesin & Menurunkan utilitas mesin \\
\hline & $\begin{array}{l}\text { Penumpukan kantong } \\
\text { setengah jadi }\end{array}$ & $\begin{array}{l}\text { Penurunan kualitas kantong setengah } \\
\text { jadi }\end{array}$ \\
\hline $\begin{array}{l}\text { Gerakan yang tidak } \\
\text { berguna }\end{array}$ & $\begin{array}{l}\text { Pengumpulan produk yang } \\
\text { cacat disekitar mesin } \\
\text { bottomer dan mesin potong }\end{array}$ & $\begin{array}{l}\text { Produk yang yang bisa di perbaiki dan } \\
\text { yang tidak bisa diperbaiki menjadi } \\
\text { tercampur dan terpaksa memilah } \\
\text { kembali }\end{array}$ \\
\hline
\end{tabular}

\section{KESIMPULAN}

Penggambaran proses produksi secara detil dilakukan dengan menggunakan Diagram SIPOC.

Tiga peta yang terpilih dilihat dari tingkat kolerasi dan kegunaannya yang bisa menggambarkan pemborosan yang ada dalam proses produksi yaitu Process Activity Mapping, Quality Filter Mapping dan Demand Amplification Mapping.

Dari pemborosan yang ditemukan dapat ditentukan akar permasalahan seperti: kelebihan produksi berdampak pada produksi kantong semen menjadi berlebih dan menambah biaya penyimpanan, departemen produksi memproduksi seperti biasa sehingga mengakibatkan kelebihan 
produksi, pada pemasalahan cacat produk berdampak pada menghambat proses produksi, adanya pemborosan material, kehilangan kesempatan pengiriman, produk reject menumpuk di area kerja, pada permasalahan pemborosan waktu tunggu berdampak pada lead time pemesanan menjadi lebih lama, utilitas mesin rendah, lebih banyak produk cacat, menurunkan utilitas mesin, penurunan kualitas kantong setengah jadi dan pada permasalahan gerakan yang tidak berguna berdampak pada produk yang yang bisa di perbaiki dan yang tidak bisa diperbaiki menjadi tercampur dan terpaksa memilah kembali

\section{DAFTAR PUSTAKA}

[1]. Gaspersz, Vincent, 2006. Continuos Cost Reduction Through Lean-Sigma Approach. PT. Gramedia Pustaka Utama : Jakarta.

[2]. Hines, P, and N. Rich, 1997. The Seven Value Stream Mapping Tools: Lean Enterprise Research centre, cardiff Business School. Cardiff, UK. International Journal of Operations \& Production Management, Vol. 17 No.1

[3]. Vanany, Iwan., 2005, Aplikasi Pemetaan Aliran Nilai Industri Kemasan Semen Jurnal Teknik Industri Universitas Kristen Petra.

[4]. Hines, P, and N. Rich, 1997. The Seven Value Stream Mapping Tools Manufacturing Operations and Supply Chain Management: Lean Approach. Thomson Leraning, London.

[5]. New, C., 1993, The Use of Throughput Efficiency as a Key Performance Measure for the New Manufacturing Era. The International Journal of Logistics Management, 4, (2), pp. 95-104.

[6]. Forrester J. 1958, 'Industrial Dynamics A Major Breakthrough For Decision Makers' Harvard Business Review July-August

[7]. Burbidge, J, 1984. Automated Production Control With A Simulation Capacity. Proceedings of the IFIP Conference WG 5-7, Copenhagen.

[8]. William J, Kolarik, 1995. Creating Quality : Concepts, System, Strategi and Tools. McgrawHill. 